\title{
The real Bigfoot: a pes from Wyoming, USA is the largest sauropod pes ever reported and the northern-most occurrence of brachiosaurids in the Upper Jurassic Morrison Formation
}

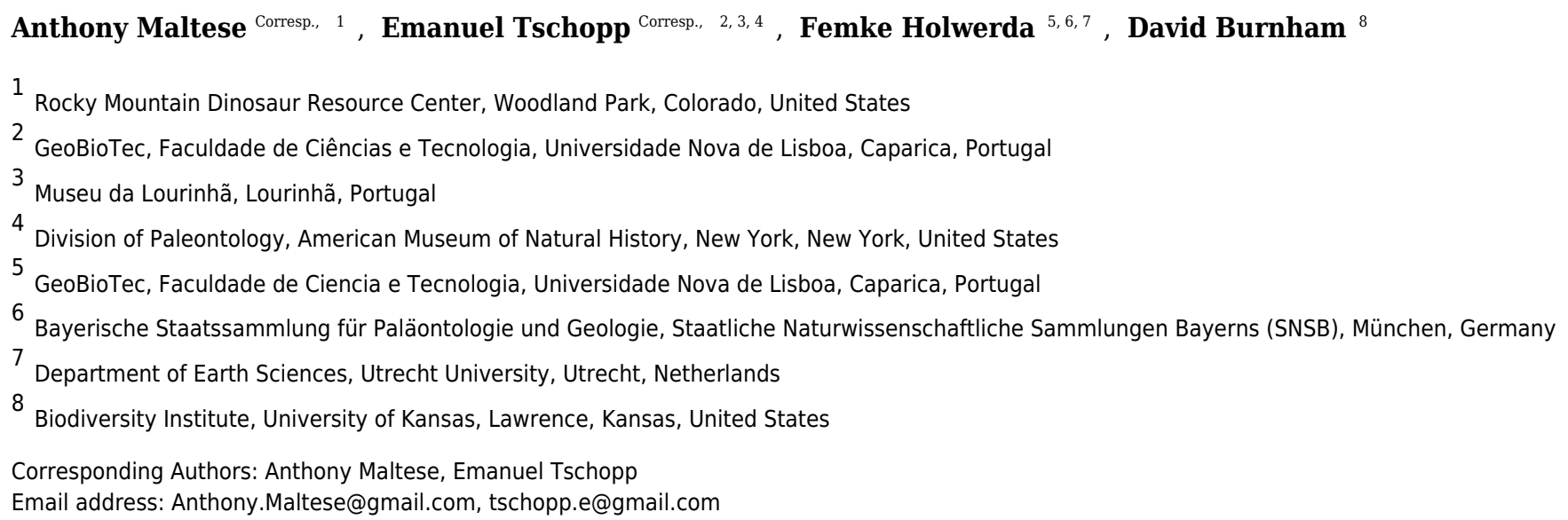

A set of associated left pedal elements of a sauropod dinosaur from the Upper Jurassic Morrison Formation in Weston County, Wyoming, is described here. Several camarasaurids, a nearly complete small brachiosaur, and a small diplodocid have been found at this locality, but none match the exceptionally large size of the pedal elements. Next to the associated pedal elements, an isolated astragalus, phalanx and ungual were found, which match the large metatarsals in size. The elements cannot be ascribed to diplodocids due to the lack of a ventral process of metatarsal I. Moreover, the morphology of metatarsal $V$ has a broad proximal end, with a long and narrow distal shaft, which differs from Camarasaurus. The size of the material and a medially beveled distal articular surface of metatarsal IV imply an identification as a brachiosaurid. This is the largest pes ever reported from a sauropod dinosaur and represents the first confirmed pedal brachiosaur elements from the Late Jurassic of North America. Furthermore, this brachiosaur material (the pes and the small nearly complete specimen) is the northernmost occurrence of brachiosaurids in the Morrison Formation. 
1 The real Bigfoot: a pes from Wyoming, USA is the largest sauropod pes ever reported and the 2 northern-most occurrence of brachiosaurids in the Upper Jurassic Morrison Formation.

3

Anthony Maltese $^{1 *}$, Emanuel Tschopp ${ }^{234}$, Femke Holwerda ${ }^{356}$, David Burnham ${ }^{7}$

Affiliations

${ }^{1}$ Rocky Mountain Dinosaur Resource Center, Woodland Park, Colorado, United States

${ }^{2}$ American Museum of Natural History, Division of Paleontology, New York, New York, United States

${ }^{3}$ GeoBioTec, Faculdade de Ciências e Tecnologia, Universidade Nova de Lisboa, Caparica, Portugal

${ }^{4}$ Museu da Lourinhã, Lourinhã, Portugal

${ }^{5}$ Staatliche Naturwissenschaftliche Sammlungen Bayerns (SNSB), Bayerische Staatssammlung für Paläontologie und Geologie, München, Germany

${ }^{6}$ Department of Earth Sciences, Utrecht University, Utrecht, Netherlands

7 University of Kansas, Biodiversity Institute, Lawrence, Kansas, United States

*Corresponding authors: Anthony.Maltese@gmail.com; etschopp@amnh.org

Running title: Large Brachiosaurid Pes

\section{Abstract}

A set of associated left pedal elements of a sauropod dinosaur from the Upper Jurassic Morrison Formation in Weston County, Wyoming, is described here. Several camarasaurids, a nearly complete small brachiosaur, and a small diplodocid have been found at this locality, but none match the exceptionally large size of the pedal elements. Next to the associated pedal elements, an isolated astragalus, phalanx and ungual were found, which match the large metatarsals in size. The elements cannot be ascribed to diplodocids due to the lack of a ventral process of metatarsal I. Moreover, the morphology of metatarsal $\mathrm{V}$ has a broad proximal end, with a long and narrow distal shaft, which differs from Camarasaurus. The size of the material and a medially beveled distal articular surface of metatarsal IV imply an identification as a brachiosaurid. This is the largest pes ever reported from a sauropod dinosaur and represents the first confirmed pedal brachiosaur elements from the Late Jurassic of North America. Furthermore, this brachiosaur material (the pes and the small nearly complete specimen) is the northernmost occurrence of brachiosaurids in the Morrison Formation.

\section{Introduction}

The Upper Jurassic (late Oxfordian to early Tithonian) Morrison Formation is famous for its abundant dinosaur material, particularly sauropods (e.g. Camarasaurus, Diplodocus, Apatosaurus, and Brachiosaurus; McIntosh, 1990a,b; Foster, 2003; Chure et al., 2006; Whitlock, 2011; Woodruff \& Foster, 2017; Tschopp \& Mateus, 2017). Occurrences of these sauropods are recorded throughout the Morrison Formation, which outcrops in eight states, but it remains unclear if the more than 20 known species cooccurred in the same place or if they were segregated geographically. This is particularly true for species that are rarely found, such as Dyslocosaurus polyonychius (McIntosh, Coombs \& Russell, 1992), Dystrophaeus viaemalae (Cope, 1877; McIntosh, 1997), Suuwassea emilieae (Harris \& Dodson, 2004), 
43 Kaatedocus siberi (Tschopp \& Mateus, 2013), and Brachiosaurus altithorax (Riggs, 1903, 1904; Bonnan \& 44 Wedel, 2004).

45 The northern exposures of the Morrison Formation are little-known compared to the ones farther south.

46 In order to test for geographical segregation among sauropods, it is therefore crucial to assess the

47 taxonomy of any specimen found in the north in as much detail as possible, no matter how incomplete

48 the specimens are. Herein, we describe a partial, potentially brachiosaurid pes from the Black Hills in

49 Wyoming. Pedal elements can be diagnostic at least at family level, sometimes even below that

50 (McIntosh, Coombs \& Russell, 1992; D'Emic, 2012; Mannion et al., 2013; Tschopp et al., 2015). Though

51 found together with Camarasaurus, there are morphological differences that show the new foot to be

52 dissimilar to both Camarasaurus specimens from this quarry. Brachiosaurid material from this site has

53 been reported in the past (Foster, 2003; Bader, Hasiotis \& Martin, 2009), but without a detailed

54 systematic assessment or description. Given that these would be the northern-most occurrences of

55 brachiosaurids in the Morrison Formation, the herein described pes adds important data to our

56 understanding of potential geographical patterning of the Morrison Formation fauna.

57

\section{Materials and methods}

59

Institutional abbreviations

61 AC, Beneski Museum of Natural History of the Amherst College, Amherst, Massachusetts, USA

62 AMNH, American Museum of Natural History, New York City, New York, USA

63 ANS, Academy of Natural Sciences, Philadelphia, Pennsylvania, USA

64 ASDM, Arizona-Sonora Desert Museum, Tucson, Arizona, USA

65 CM, Carnegie Museum of Natural History, Pittsburgh, Pennsylvania, USA

66 CMC-PV, Cincinnati Museum of Natural History and Science, Cincinnati, $\mathrm{OH}$

67 CPT, Museo de la Fundación Conjunto Paleontológico de Teruel-Dinópolis, Aragón, Spain

68 DFMMh, Dinosaurier-Freilichtmuseum, Münchehagen, Germany

69 DMNS, Denver Museum of Nature and Science, Denver, Colorado, USA (previously DMNH)

70 FMNH, Field Museum of Natural History, Chicago, Illinois, USA

71 GMNH-PV, Gunma Museum of Natural History, Gunma, Japan

72 IANIGLA-PV, Instituto Argentino de Nivologia Glaciologia y Ciencias Ambientales, Mendoza, Argentina

73 KUVP, Kansas University Museum of Natural History, Vertebrate Paleontology, Lawrence, Kansas, USA

74 Mal, Malawi Department of Antiquities Collection, Lilongwe and Nguludi, Malawi

75 MB.R., Museum für Naturkunde Berlin, Berlin, Germany

76 MCF-PHV, Museo 'Carmen Funes', Plaza Huincul, Neuquén, Argentina

77 MNHN, Muséum National d'Histoire Naturelle, Paris, France 
MNN, Musee National du Niger, Niamey, Republic of Niger

MPCA-PV, Colección de Paleovertebrados de la Museum Provincial de Cipolletti 'Carlos Ameghino', Cipolletti, Rio Negro Province, Argentina

MPM, Museo Padre Molina, Rio Gallegos, Santa Cruz, Argentina

MPZ, Museo Paleontológico de Zaragoza, Zaragoza, Spain

MUCPv, Museo de Geología y Paleontología Universidad Nacional de Comahue, Argentina NHMUK, Natural History Museum, London, United Kingdom

NMMNH, New Mexico Museum of Natural History and Science, Albuquerque, New Mexico, USA NSMT, National Science Museum, Tokyo, Japan

SMA, Sauriermuseum Aathal, Switzerland

SMNS, Staatliches Museum für Naturkunde, Stuttgart, Germany

UNCUYO-LD, Universidad Nacional de Cuyo, Laboratorio de Dinosaurios, Mendoza, Argentina UNPSJB-PV, Universidad Nacional de la Patagonia San Juan Bosco, Comodoro Rivadavia, Argentina YPM, Yale Peabody Museum of Natural History, New Haven, Connecticut, USA ZDM, Zigong Dinosaur Museum, Zigong, China

ZPAL, Institute of Paleobiology, Polish Academy of Sciences, Warsaw, Poland

\section{Material and Association}

The pes described herein consists of an astragalus (KUVP 142200), metatarsals I to V, four non-ungual pedal phalanges, one ungual (KUVP 129724), an additional non-ungual phalanx (KUVP 133862), and a second ungual (KUVP 144767). It was found at the Bobcat Pit site in Weston County in the Black Hills in north-eastern Wyoming (see Figure 1A). It has been mentioned in Bader, Hasiotis \& Martin (2009), but never described in detail. In addition to the elements belonging to the pes described herein (KUVP 129724, 133862, 142200, 144767, Figure 1B,C), Bobcat Pit has produced several specimens belonging to camarasaurid, diplodocid, and brachiosaurid sauropods (Bader, Hasiotis \& Martin, 2009). During a 1998 expedition led by the University of Kansas, the sauropod pes was found underneath the tail of the Camarasaurus KUVP 129716, with the phalanges scattered around the skeleton (Figure 1C). Metatarsals I, II, III, and IV of KUVP 129724 were closely associated, whereas metatarsal V and a pedal ungual (likely php III-3) were found nearby. Three proximal phalanges (field numbers BP013, BP194 and BP208; see Table 1) were recovered about a meter away from the metatarsals with a proximal phalanx (field number BP185) slightly further away. Phalanx KUVP 133862 was discovered during preparation of a large field jacket containing caudal elements of Camarasaurus KUVP 129716. The astragalus KUVP 142200 was collected beneath KUVP 129713. A second large claw, likely php I-2, was discovered when the site was later reopened by another excavation crew. This claw was molded and a high fidelity cast was donated to KUVP, bearing the number KUVP 144767. All elements described herein are referred to the same animal 
114

115

116

117

118

119

120

121

122

123

124

125

126

127

128

129

130

131

132

133

134

135

136

137

138

139

140

141

142

143

144

145

146

147

148

149

150

151

152

153

154

155

as KUVP 129724 due to their great size, relative proximity in the quarry, and lack of any duplication in the elements.

Based on comparisons with articulated camarasaurid and brachiosaurid pedes, we interpret the phalanges as php I-1, II-1, III-1, and possible IV-1 and V-1, and the unguals as probably representing unguals I and III. However, given that the specimen was found disarticulated and incomplete, we refrain from reconstructing a pedal formula.

The elements of KUVP 129724, the astragalus KUVP 142200, the phalanx KUVP 133862, and the ungual KUVP 144767 were not consistent in size with the Camarasaurus specimen they were found with (KUVP 129716), nor with a second, larger Camarasaurus specimen from the same quarry. The Camarasaurus KUVP 129716 was nearly complete and included almost all the pedal material in articulation. All pedal bones from this specimen are duplicated in KUVP 129724, so it is certain the large pes does not belong to this specimen. A larger Camarasaurus (KUVP 129713) was excavated in 1997, approximately $7 \mathrm{~m}$ adjacent in the same quarry. However, this individual is also much smaller than the new pes. Finally, all proximal phalanges display a peculiar bone texture on their proximal articular surfaces. These surfaces are marked by irregularly undulating grooves generally extending from the margins towards the center. Such a texture is likely due to remodeling in response to specific stresses in vivo, supporting the interpretation that all phalanges belong to a single pes, because all the joints between metatarsals and phalanges seem to be equally affected. As specimens at this quarry site generally occur as discreet skeletons rather than a mass of bonebed elements, these considerations suggest it is very likely the pes is a slightly scattered assemblage of elements from a single individual.

\section{Excavation and Preparation}

The pes and astragalus were excavated from a mudstone deposit, with some encrustation of caliche on the bones, especially around the articular ends. The softer matrix was removed primarily with X-acto knives and air abrasion utilizing sodium bicarbonate abrasives. Concretionary material was removed much more slowly employing Aro and Chicago Pneumatic air scribes and air abrasion with Dolomite (and very seldom glass beads and Aluminum Oxide) abrasives. All elements were scanned using an Artec Spider handheld structured light unit and processed using Artec Studio 12 software. Individual scan files were organized and arranged in Blender software to produce figure images. The three-dimensional models are available through KUVP for research purposes.

\section{Description and Comparison}

Astragalus

The astragalus KUVP 142200 (Figure 2) is slightly wider transversely than proximodistally tall and anteroposteriorly long (Table 1). It has neosauropod affinities based on the ascending process that reaches the posterior margin (Wilson \& Sereno, 1998). As in most sauropods, it is wedge-shaped, with a reduced medial corner. However, it differs from diplodocids and camarasaurids by a more pentagonal instead of subtriangular outline in posterior view (Figure 3). The extension of the medial corner is similar to the brachiosaurids Giraffatitan and Lusotitan, which have a relatively shorter and more rounded medial end than Janenschia and Camarasaurus (Figure 3; Janensch, 1961; Mannion et al., 2013; Tschopp et al., 2015). The lateral surface of the astragalus KUVP 142200 received the fibula. It faces laterally, and 
156

157

158

159

160

161

162

163

164

165

166

167

168

169

170

171

172

173

174

175

176

177

178

179

180

181

182

183

184

185

186

187

188

189

190

191

192

193

194

195

196

197

has no distinct bony shelf that would have supported the fibula, unlike the condition in diplodocids (Whitlock, 2011; Tschopp, Mateus \& Benson, 2015).

\section{Metatarsals}

The pes KUVP 129724 (Figure 2) has the typical shape of a eusauropod pes, having a spreading, asymmetrical metatarsus with an entaxonic structure, where $\mathrm{mt} \mathrm{I}$ is the most robust element (Table 1; Coombs Jr, 1975; Cooper, 1984; Mclntosh, 1990b; Farlow, 1992; Upchurch, 1998; Wilson \& Sereno, 1998; Bonnan, 2005).

The metatarsals (Figure 2) are generally hour-glass shaped with transversely and dorsoplantarly expanded proximal and distal articular surfaces. As is typical for eusauropods, the $\mathrm{mt} V$ differs from the rest in having a much more widely expanded proximal end compared to the distal one, resulting in a paddle-like shape (Bonnan, 2005). The distal articular surfaces bear distinct condyles in $\mathrm{mt} \mathrm{I}$, which gradually decrease in size and distinctiveness towards $\mathrm{mt} V$ with its gently rounded surface without any differentiation into separate condyles.

The metatarsals of KUVP 129724 can be distinguished from diplodocid ones by the absence of a welldeveloped posterolateral process on the distal articular surfaces of $\mathrm{mt} \mathrm{I}$ and II, and from flagellicaudatan metatarsals more generally by the lack of distinct rugose ridges close to the dorsolateral edges (Mclntosh, Coombs \& Russell, 1992; Harris, 2007; Whitlock, 2011; Tschopp et al., 2015; Tschopp, Mateus \& Benson, 2015).

Metatarsal I (Figure 2) has a subrectangular to D-shaped proximal articular surface, with a concave lateral and a convex medial edge. The surface is dorsoplantarly higher than transversely wide. The dorsolateral corner of the proximal articular surface bears a distinct, tapered projection, as occurs in the $\mathrm{mt}$ I of the early brachiosaurid Vouivria (Figure 4; Mannion, Allain \& Moine, 2017). The proximal articular surface is strongly beveled compared to the long axis of the shaft, whereas the distal articular surface is approximately perpendicular to it. The distal articular surface is usually similarly beveled as the proximal one in flagellicaudatans (Figure 4; Janensch, 1961: Beilagen P, R; McIntosh, Coombs \& Russell, 1992: fig. 3; Harris, 2007: fig. 8; Tschopp \& Mateus, 2017: fig. 75).

Metatarsal II (Figure 2) is slightly longer than $\mathrm{mt} \mathrm{I}$ (Table 1). It has a subtrapezoid proximal articular surface with an expanded dorsolateral corner. Both the medial and the lateral edges are dorsoplantarly straight in proximal view (Figure 5A). As such, it differs from many diplodocids, in which medial and lateral edges are concave (Tschopp, Mateus \& Benson, 2015; Tschopp \& Mateus, 2017), as well as from the rather subquadrangular shape of the proximal articular surface of $\mathrm{mt}$ II in Camarasaurus (Figure 5A; Tschopp et al., 2015). It most resembles the proximal outline of mt II of Giraffatitan brancai (Figure 5A), although these also have slightly concave medial and lateral edges (Janensch, 1961; MB.R.2268, E. Tschopp, pers. obs. 2014). The shaft of mt II of KUVP 129724 is stout, but less so than in $\mathrm{mt}$ I.

Metatarsal III (Figure 2) is the most slender and longest of the five elements (Table 1). The proximal articular surface was damaged during excavation. What remains of the proximal articular surface indicates that the surface had a rhomboid to slightly sheared subrectangular outline, probably similar to Ligabuesaurus (D’Emic, Wilson \& Williamson, 2011). It is dorsoplantarly higher than transversely wide. 
198

199

200

201

202

203

204

205

206

207

208

209

210

211

212

213

214

215

216

217

218

219

220

221

222

223

224

225

226

227

228

229

230

231

232

233

234

235

236

237

238

239

The shaft expands considerably transversely towards the proximal and distal ends. The dorsal surface of the shaft is relatively flat and straight, whereas the plantar surface is concave in lateral view. The distal articular surface has distinct medial and lateral condyles.

Metatarsal IV (Figure 2) is slightly more robust than $\mathrm{mt}$ III. It has a subtriangular proximal articular surface (Figure 6A), which is different from the L-shaped one of Camarasaurus (Figure 6A; Tschopp et al., 2015), and the kidney-shaped surface of the putative brachiosaurid Europasaurus (Figure 6A; DFMMh FV886.3; E. Tschopp, pers. obs. 2014). The distal articular surface is beveled medially, so that the medial side of the bone is shorter than the lateral one. Such a beveling has been identified as a synapomorphy for Brachiosauridae by D'Emic (2012) and Mannion et al. (2013).

Metatarsal V (Figure 2) has a widely expanded proximal end, which strongly tapers into a long slender shaft, similar to the brachiosaurids Giraffatitan brancai (Janensch, 1961) and Sonorasaurus (D'Emic, Foreman \& Jud, 2016). In Janenschia and Camarasaurus, the expansion is wide too, but it extends further distally along the shaft (Figure 7; Bonaparte, Heinrich \& Wild, 2000; Tschopp et al., 2015), whereas in many diplodocids, the proximal expansion is similarly developed as in KUVP 129724 (Figure 7; Janensch, 1961; Tschopp \& Mateus, 2017). The distal articular surface of mt V of KUVP 129724 is only weakly transversely expanded compared to minimum shaft width, which is similar to Camarasaurus, but different from flagellicaudatans (Janensch, 1961; Remes, 2009; Tschopp et al., 2015; Tschopp \& Mateus, 2017, see Supplementary Table and Figure 7 for $\mathrm{mt} V$ proportions). The distal articular surface of $\mathrm{mt} V$ of KUVP 129724 is less expanded in relation to proximodistal length than the metatarsals $V$ of both Camarasaurus and diplodocids, and are instead comparable to the somphospondylians Tastavinsaurus and MUCPv-1533 (Canudo, Royo-Torres \& Cuenca-Bescós, 2008; González Riga, Calvo \& Porfiri, 2008) and the brachiosaurids Cedarosaurus and Sonorasaurus (Figure 7; D’Emic, 2013; D’Emic, Foreman \& Jud, 2016).

\section{Pedal phalanges}

The phalanges (Figure 2) are generally wider than long (Table 1) and have distinctly expanded proximal articular surfaces and no collateral ligament pits, which is typical for eusauropods (Upchurch, 1998;

Wilson \& Sereno, 1998; Wilson, 2002; Upchurch, Barrett \& Dodson, 2004). In php II-1, III-1, and IV-1, also the distal articular surfaces are expanded transversely.

Phalanx php I-1 (Figure 2) is just slightly wider than dorsoplantarly high, both proximally and distally, resembling the proportions of Giraffatitan (Janensch, 1961) and diplodocids (Tschopp \& Mateus, 2017), but not Camarasaurus (Tschopp et al., 2015). The proximal articular surface lacks the plantar "lip" typical for diplodocids (Upchurch, Tomida \& Barrett, 2004; Whitlock, 2011; Tschopp, Mateus \& Benson, 2015). The distal articular surface projects slightly dorsomedially, resulting in a distinctly concave medial edge. This corner is equally developed in Giraffatitan (Janensch, 1961) and Sonorasaurus (D'Emic, Foreman \& Jud, 2016), but no projection occurs in any other sauropod taxon known to us (Figure 8).

The putative php II-1 and III-1 of KUVP 129724 (Figure 2) are relatively short, compared to Giraffatitan (Janensch, 1961), and more similar in proportion to Camarasaurus (Tschopp et al., 2015). However, the 
240

241

242

243

244

245

246

247

248

249

250

251

252

253

254

255

256

257

258

259

260

261

262

263

264

265

266

267

268

269

270

271

272

273

274

275

276

277

278

279

280

281

distal condyles of php III-1 of KUVP 129724 are less distinct in dorsal view than in Camarasaurus (Tschopp et al., 2015), and resemble more the state in Giraffatitan (Janensch, 1961).

The other two non-ungual phalanges do not provide any particular morphological information for comparative purposes. Phalanx IV-1 has a very irregular dorsal surface (Figure 2). The smallest element (KUVP 133862) is a nubbin-like bone typical for the reduced terminal, non-ungual phalanges of digits IV and $\mathrm{V}$ of most neosauropods (Bonnan, 2005).

\section{Pedal unguals}

Two unguals were recovered with the pedal elements (Figure 2). The larger of the two (KUVP 144767; interpreted to be php I-2 herein) has the typical sickle-shape of eusauropod unguals (Wilson \& Sereno 1998), whereas the smaller ungual (part of KUVP 129724; interpreted to be php III-4) is rather straight (Figure 9). The high dorsal projection of the proximal articular surface is however also present in Giraffatitan (Janensch, 1961) and Sonorasaurus (D'Emic, Foreman \& Jud, 2016). The proximal and distal outlines resemble Giraffatitan (Janensch, 1961). The scalene cross-section of the unguals differs from the isosceles shape of Camarasaurus (Figure 9; Tschopp et al. 2015).

\section{Discussion}

\section{Systematics}

The morphological comparisons lead to an identification of the pes as belonging to Titanosauriformes, and more specifically Brachiosauridae, in particular due to the orientation of the distal articular surface of $\mathrm{mt}$ IV that was recovered as a synapomorphy for the clade in two independent phylogenetic analyses (D'Emic, 2012; Mannion et al., 2013). In addition, the elongation of $\mathrm{mt} V$ is most similar to titanosauriform taxa sampled herein (see Figure 7 and Supplementary Table); Camarasaurus has more widely expanded proximal and distal articular surfaces relative to proximodistal length, whereas diplodocids all have more widely expanded distal articular surfaces. The morphology of the phalanx php $\mathrm{I}-1$, with its rounded proximal articular surface and the dorsomedial projection on the distal articular surface strongly suggest a close affinity with the brachiosaurids Giraffatitan and Sonorasaurus. Finally, the relatively straight ungual php III-3 of KUVP 129724 resembles the latter two taxa most and its scalene triangle cross section differs substantially from the isosceles triangle cross section of Camarasaurus KUVP 129716 (A. Maltese, pers. obs. 2018). This shape rarely occurs outside of Brachiosauridae. The features distinguishing KUVP 129724 from Giraffatitan are most likely representing differences at a lower taxonomic level within Brachiosauridae, given that many of them are more variable among eusauropods than the traits mentioned above.

The only currently known titanosauriform taxon from the Morrison Formation is Brachiosaurus altithorax. The type locality for this species is close to the town of Grand Junction, Colorado (Riggs, 1903, 1904; Figure 3), and several other localities have been reported to have produced brachiosaurid material in the meantime (Jensen, 1987; Curtice, Stadtman \& Curtice, 1996; Carpenter \& Tidwell, 1998; Bonnan \& Wedel, 2004; Taylor, 2009; Bader, Hasiotis \& Martin, 2009). However, the absolute number of brachiosaurid specimens from the Morrison Formation is still low relative to other sauropods, and none of these specimens preserve any bones from the lower hindleg (Taylor, 2009), so that no overlapping 
282

283

284

285

286

287

288

289

290

291

292

293

294

295

296

297

298

299

300

301

302

303

304

305

306

307

308

309

310

311

312

313

314

315

316

317

318

319

320

321

322

323

material of Brachiosaurus exists with which the pes described herein could be compared. Therefore, even though attribution to Brachiosaurus seems reasonable, we cautiously refer KUVP 129724, 133862, 142200, and KUVP 144767 to Brachiosauridae indet.

\section{The largest neosauropod pes}

Although the taxonomic position of the new specimen cannot be determined for certain, it does represent a dinosaur of enormous proportions. Indeed, the metatarsals of KUVP 129724 are slightly larger than the largest ones of Giraffatitan, and they are considerably larger than those of

Dreadnoughtus, which was reported to be one of the largest sauropods ever found (Table 2; Lacovara et al., 2014). The only other sauropod pes known so far that is close to these proportions is from the nonneosauropod eusauropod Turiasaurus riodevensis from the Late Jurassic of Spain (Royo-Torres, Cobos \& Alcalá, 2006; R. Royo-Torres, pers. comm. 2018).

Based on the hindlimb proportions of the brachiosaurid Vouivria (Mannion, Allain \& Moine, 2017), we estimated a femur length of $2071 \mathrm{~mm}$ and a tibia length of $1220 \mathrm{~mm}$ for KUVP 129724. This is slightly larger (2\%) than the type specimen of Brachiosaurus altithorax (2030 mm femur length; Riggs, 1903). Assuming that the cartilage caps on the proximal and distal articular surfaces of the longbones would increase their length by approximately 10\% (Schwarz, Wings \& Meyer, 2007; Bonnan et al., 2010; Holliday et al., 2010), this would result in a hip height of approximately $3.99 \mathrm{~m}$. Although this appears to be the largest pes reported to date, traces and other incomplete body fossils show that the pes described herein does not represent the maximum body size of sauropod dinosaurs. Some of the largest sauropods such as Argentinosaurus or Patagotitan do not preserve pedal material but have femur lengths that considerably exceed our estimate for KUVP 129724 (Argentinosaurus: 2557 mm, estimated based on incomplete femur; Patagotitan: 2360 mm; (Mazzetta, Christiansen \& Fariña, 2004; Carballido et al., 2017). The largest sauropod tracks from the Broome Sandstone of Australia are $>1100 \mathrm{~mm}$ in diameter, indicating a similar hip height as calculated for KUVP 129724 herein (> $3.41 \mathrm{~m}$; Salisbury et al., 2016). However, all these finds are from the Cretaceous, so that the type specimen of Brachiosaurus altithorax and the pedal elements described herein still represent the largest individual specimens found in the Morrison Formation, only matched in size during the same period by Turiasaurus from Spain and Giraffatitan from Tanzania. Given that the type specimen of Brachiosaurus altithorax was found in western Colorado (Riggs 1904) and the pes described herein in northeastern Wyoming, this shows that sauropods with very large body size were distributed across wide ranges in the Morrison Formation.

\section{Brachiosaurid distribution in the Late Jurassic of North America}

Our detailed description and systematic assessment of the pedal elements KUVP 129724, 133862, 142200, and 144767 confirms the presence of large-sized brachiosaurids in the Upper Jurassic Morrison Formation of the Black Hills. Together with the small-sized brachiosaur mentioned in Bader et al. (2009), this pes is the northern-most occurrence of this taxon reported so far in the Late Jurassic of North America (Figure 10). If the material described herein belonged to the currently only known Late Jurassic North American species Brachiosaurus altithorax, this taxon would cover a range of latitudes across the Morrison Formation. Brachiosaurids, like camarasaurids, were sauropods with broad-crowned teeth, which could process relatively tougher vegetation than the peg-like diplodocoid teeth (Janensch, 1935; Calvo, 1994; Wiersma \& Sander, 2016). It would, therefore, seem reasonable to assume they could cover 
324 a wide range of vegetational zones. Camarasaurids are also known to (seasonally) migrate (Fricke,

325 Hencecroth \& Hoerner, 2011), and Camarasaurus specimens have been found from New Mexico to

326 Montana (Ikejiri, 2005; Woodruff \& Foster, 2017). Given the similarities in tooth crown morphology in the

327 two genera, brachiosaurs could have displayed similar geographical spreading and/or migrational habits

328 as camarasaurids. However, additional information will be needed to assess species diversity within

329 brachiosaurids of the Morrison Formation, and to understand in more detail how their distribution, the

330 climate, and vegetation changed throughout the time of deposition of the formation. This is outside of

331 the scope of the current study.

332

333

\section{Conclusion}

334 We present the first brachiosaurid pedal elements from the Late Jurassic of North America. The pes represents the largest sauropod pes described to date. Size estimations scaled due to lack of anatomical overlap indicate that these pedal elements belonged to a brachiosaur slightly larger than the holotype of Brachiosaurus altithorax. Moreover, this pes and a small specimen of a brachiosaur from the same quarry represent the northernmost occurrences of the taxon in the Morrison Formation.

\section{Acknowledgements}

341

The pes described herein was found during an expedition spearheaded by the late Larry Martin of KUVP.

K. Bader, J. Richard and M. Christopher prepared the individual bones. The late Jack McIntosh first proposed this pes could belong to Brachiosaurus. We thank the following people for access to comparative material: Nils Knötschke (DFMMh), Daniela Schwarz (MB.R.), Paul Barrett and Sandra Chapman (NHMUK), Dan Brinkman and Jacques Gauthier (YPM). Mike Triebold generously provided the

346 $3 \mathrm{D}$ scanning and rendering equipment for the figures. Chris Beard is thanked for enabling scanning at KUVP. A special thanks goes to Matthew Christopher for his expert aid in manipulating the 3D models for figures. Jay Nair shared photographs and measurements of Janenschia. We are grateful to editor Matthew Wedel, reviewer Mike Taylor, and two anonymous reviewers, whose comments and helpful suggestions greatly improved this paper.

351

352

353

\section{References}

355

Bader KS., Hasiotis ST., Martin LD. 2009. Application of forensic science techniques to trace fossils on dinosaur bones from a quarry in the Upper Jurassic Morrison Formation, Northeastern sauropod from the Tendaguru beds of Tanzania and a discussion on the systematic value of procoelous caudal vertebrae in the Sauropoda. Palaeontographica Abteilung A 256:25-76. 
362 Bonnan MF., Sandrik JL., Nishiwaki T., Wilhite DR., Elsey RM., Vittore C. 2010. Calcified cartilage shape in

363

364

365

366

367

368

369

370

371

372

373

374

375

376

377

378

379

380

381

382

383

384

385

archosaur long bones reflects overlying joint shape in stress-bearing elements: Implications for nonavian dinosaur locomotion. The Anatomical Record: Advances in Integrative Anatomy and Evolutionary Biology 293:2044-2055. DOI: 10.1002/ar.21266.

Bonnan, M.F., 2005. Pes anatomy in sauropod dinosaurs: Implications for functional morphology, evolution, and phylogeny, in: Tidwell, V., Carpenter, K. (Eds.), Thunder-Lizards: The Sauropodomorph Dinosaurs. Indiana University Press, Bloomington, pp. 346-380.

Bonnan MF., Wedel MJ. 2004. First occurrence of Brachiosaurus (Dinosauria: Sauropoda) from the Upper Jurassic Morrison Formation of Oklahoma. PaleoBios 24:13-21.

Calvo JO. 1994. Jaw mechanics in sauropod dinosaurs. Gaia 10:183-193.

Canudo Jl., Royo-Torres R., Cuenca-Bescós G. 2008. A new sauropod: Tastavinsaurus sanzi gen. et sp. nov. from the Early Cretaceous (Aptian) of Spain. Journal of Vertebrate Paleontology 28:712731.

Carballido JL., Pol D., Otero A., Cerda IA., Salgado L., Garrido AC., Ramezani J., Cúneo NR., Krause JM. 2017. A new giant titanosaur sheds light on body mass evolution among sauropod dinosaurs. In: Proc. R. Soc. B. The Royal Society, 20171219.

Carpenter K., Tidwell V. 1998. Preliminary description of a Brachiosaurus skull from Felch quarry 1, Garden Park, Colorado. Modern Geology 2:69-84.

Chure, D.J., Litwin, R., Hasiotis, S.T., Evanoff, E., Carpenter, K., 2006. The fauna and flora of the Morrison Formation: 2006. Paleontology and Geology of the Upper Jurassic Morrison

Coombs Jr, W.P., 1975. Sauropod habits and habitats. Palaeogeography, Palaeoclimatology, Palaeoecology 17, 1-33. https://doi.org/10.1016/0031-0182(75)90027-9

Cooper, M.R., 1984. A reassessment of Vulcanodon karibaensis Raath (Dinosauria: Saurischia) and the origin of the Sauropoda. Palaeontologia africana 25, 203-231. 
386

387

388

389

390

391

392

393

394

395

396

397

398

399

400

401

402

403

404

405

406

407

408

409

Cope ED. 1877. On a dinosaurian from the Trias of Utah. Proceedings of the American Philosophical Society 16:579-584.

Curtice BD., Stadtman KL., Curtice LJ. 1996. A reassessment of Ultrasauros macintoshi (Jensen, 1985). Museum of Northern Arizona Bulletin 60:87-95.

D’Emic MD., Foreman BZ., Jud NA. 2016. Anatomy, systematics, paleoenvironment, growth, and age of the sauropod dinosaur Sonorasaurus thompsoni from the Cretaceous of Arizona, USA. Journal of Paleontology 90:102-132. DOI: 10.1017/jpa.2015.67.

D'Emic MD. 2013. Revision of the sauropod dinosaurs of the Lower Cretaceous Trinity Group, southern USA, with the description of a new genus. Journal of Systematic Palaeontology 11:707-726. DOI: 10.1080/14772019.2012.667446.

D'Emic, MD., 2012. The early evolution of titanosauriform sauropod dinosaurs. Zoological Journal of the Linnean Society 166, 624-671. https://doi.org/10.1111/j.1096-3642.2012.00853.x

D’Emic M., Wilson JA., Williamson TE. 2011. A sauropod dinosaur pes from the latest Cretaceous of North America and the validity of Alamosaurus sanjuanensis (Sauropoda, Titanosauria). Journal of Vertebrate Paleontology 31:1072-1079. DOI: 10.1080/02724634.2011.595856.

Farlow, J.O., 1992. Sauropod tracks and trackmakers integrating the ichnological and skeletal records. Zubia 10, 89-138.

Foster, J.R., 2003. Paleoecological analysis of the vertebrate fauna of the Morrison Formation (Upper Jurassic), Rocky Mountain Region, U.S.A. New Mexico Museum of Natural History and Science Bulletin 23, 2-100.

Fricke HC., Hencecroth J., Hoerner ME. 2011. Lowland-upland migration of sauropod dinosaurs during the Late Jurassic epoch. Nature.

González Riga BJ., Calvo JO., Porfiri J. 2008. An articulated titanosaur from Patagonia (Argentina): new evidence of neosauropod pedal evolution. Palaeoworld 17:33-40. 
410 Harris, J.D., 2007. The appendicular skeleton of Suuwassea emilieae (Sauropoda: Flagellicaudata) from 411 the Upper Jurassic Morrison Formation of Montana (USA). Geobios 40, 501-522.

412 Harris, J.D., Dodson, P., 2004. A new diplodocoid sauropod dinosaur from the Upper Jurassic Morrison 413 Formation of Montana, USA. Acta Palaeontologica Polonica 49, 197-210.

414 Holliday CM., Ridgely RC., Sedlmayr JC., Witmer LM. 2010. Cartilaginous epiphyses in extant archosaurs 415 and their implications for reconstructing limb function in dinosaurs. PLoS One 5:e13120.

416 Ikejiri T. 2005. Distribution and biochronology of Camarasaurus (Dinosauria, Sauropoda) from the 417 Jurassic Morrison Formation of the Rocky Mountain Region. New Mexico Geological Society Field Conference Guidebook, Geology of the Chama Basin 56:367-379.

Janensch, W., 1961. Die Gliedmassen und Gliedmassengürtel der Sauropoden der Tendaguru-Schichten. Palaeontographica-Supplementbände 4, 177-235.

421

422

423

424

425

426

427

428

429

430

431

432

433

Janensch W. 1935. Die Schädel der Sauropoden Brachiosaurus, Barosaurus und Dicraeosaurus aus den Tendaguruschichten Deutsch-Ostafrikas. Palaeontographica Supplement 7:145-298.

Jensen JA. 1987. New brachiosaur material from the Late Jurassic of Utah and Colorado. Western North American Naturalist 47:592-608.

Mannion, P.D., Allain, R., Moine, O., 2017. The earliest known titanosauriform sauropod dinosaur and the evolution of Brachiosauridae. PeerJ 5, e3217.

Mannion, P.D., Upchurch, P., Barnes, R.N., Mateus, O., 2013. Osteology of the Late Jurassic Portuguese sauropod dinosaur Lusotitan atalaiensis (Macronaria) and the evolutionary history of basal titanosauriforms. Zoological Journal of the Linnean Society 168, 98-206. https://doi.org/10.1111/zoj.12029

Mazzetta GV., Christiansen P., Fariña RA. 2004. Giants and Bizarres: Body Size of Some Southern South American Cretaceous Dinosaurs. Historical Biology 16:71-83. DOI: 10.1080/08912960410001715132. 
434 McIntosh JS. 1997. The saga of a forgotten sauropod dinosaur. In: Dinofest International Proceedings. $435 \quad$ Philadelphia, USA: Academy of Natural Sciences, 7-12.

436 Mclntosh, J.S., Coombs, W.P., Russell, D.A., 1992. A new diplodocid sauropod (Dinosauria) from

437 Wyoming, USA. Journal of Vertebrate Paleontology 12, 158-167.

438

439

440

441

442

443

444

445

446

447

448

449

450

451

452

453

454

455

456 401.

Remes K. 2009. Taxonomy of Late Jurassic diplodocid sauropods from Tendaguru (Tanzania). Fossil Record 12:23-46.

Riggs, E.S., 1904. Structure and relationships of opisthocoelian dinosaurs: the Brachiosauridae. Field Columbian Museum, Geological Series 2 2, 229-247.

Riggs ES. 1903. Brachiosaurus altithorax, the largest known dinosaur. American Journal of Science, Series 4 15:299-306.

Royo-Torres R., Cobos A., Alcalá L. 2006. A giant European dinosaur and a new sauropod clade. Science 314:1925-1927.

Salisbury SW., Romilio A., Herne MC., Tucker RT., Nair JP. 2016. The Dinosaurian Ichnofauna of the Lower Cretaceous (Valanginian-Barremian) Broome Sandstone of the Walmadany Area (James Price Point), Dampier Peninsula, Western Australia. Journal of Vertebrate Paleontology 36:1152.

Schwarz D., Wings O., Meyer CA. 2007. Super sizing the giants: first cartilage preservation at a sauropod dinosaur limb joint. Journal of the Geological Society 164:61. 
457 Taylor MP. 2009. A re-evaluation of Brachiosaurus altithorax Riggs 1903 (Dinosauria, Sauropoda) and its

458 generic separation from Giraffatitan brancai (Janensch 1914). Journal of Vertebrate

$459 \quad$ Paleontology 29:787-806.

460 Tschopp, E., Mateus, O., 2017. Osteology of Galeamopus pabsti sp. nov. (Sauropoda: Diplodocidae), with 461 implications for neurocentral closure timing, and the cervico-dorsal transition in diplodocids.

$462 \quad$ PeerJ 5, e3179. https://doi.org/10.7717/peerj.3179

463 Tschopp, E., Mateus, O., 2013. The skull and neck of a new flagellicaudatan sauropod from the Morrison 464 Formation and its implication for the evolution and ontogeny of diplodocid dinosaurs. Journal of 465 Systematic Palaeontology 11, 853-888. https://doi.org/10.1080/14772019.2012.746589

466 Tschopp, E., Mateus, O., Benson, R.B.J., 2015a. A specimen-level phylogenetic analysis and taxonomic 467 revision of Diplodocidae (Dinosauria, Sauropoda). PeerJ 3, e857.

$468 \quad$ https://doi.org/10.7717/peerj.857

469 Tschopp, E., Wings, O., Frauenfelder, T., Brinkmann, W., 2015b. Articulated bone sets of manus and 470 pedes of Camarasaurus (Sauropoda, Dinosauria). Palaeontologia Electronica 18, 1-65.

471 Upchurch, P., Barrett, P.M., Dodson, P., 2004. Sauropoda, in: Weishampel, D.B., Dodson, P., Osmólska, 472 H. (Eds.), The Dinosauria. Second Edition. University of California Press, Berkeley, CA, pp. 259-

473 322.

474 Upchurch P., Tomida Y., Barrett PM. 2004. A new specimen of Apatosaurus ajax (Sauropoda:

475 Diplodocidae) from the Morrison Formation (Upper Jurassic) of Wyoming, USA. National Science $476 \quad$ Museum Monographs 26:1-118.

477 Upchurch, P., 1998. The phylogenetic relationships of sauropod dinosaurs. Zoological Journal of the $478 \quad$ Linnean Society 124, 43-103.

479 Whitlock, J.A., 2011. A phylogenetic analysis of Diplodocoidea (Saurischia: Sauropoda). Zoological 480 Journal of the Linnean Society 161, 872-915. https://doi.org/10.1111/j.1096-3642.2010.00665.x 
481 Wiersma K., Sander PM. 2016. The dentition of a well-preserved specimen of Camarasaurus sp.:

482 implications for function, tooth replacement, soft part reconstruction, and food intake. PalZ:1-

483 17. DOI: 10.1007/s12542-016-0332-6.

484 Wilson, J.A., 2002. Sauropod dinosaur phylogeny: critique and cladistic analysis. Zoological Journal of the $485 \quad$ Linnean Society 136, 215-275.

486

487

488

489

490

491

492

493

494

495

496

497

498

499

500

501

502

503

504

505

506

507

508

509

510

511

512

513

514

515

Wilson, J.A., Sereno, P.C., 1998. Early evolution and higher-level phylogeny of sauropod dinosaurs. Journal of Vertebrate Paleontology 18, 1-79.

Woodruff DC., Foster JR. 2017. The first specimen of Camarasaurus (Dinosauria: Sauropoda) from Montana: The northernmost occurrence of the genus. PloS one 12:e0177423.

\section{Figure and Table legends}

Figure 1: Location $(A)$ and quarry maps $(B, C)$ of Bobcat Pit in Weston County, Wyoming. The astragalus and pes described herein (KUVP 129724, 133862, 142200, 144767) were found associated with the Camarasaurus skeletons KUVP 129713 and 129716.

Figure 2: Single bones of the brachiosaurid pes described herein. Astragalus KUVP 142200 in proximal, distal, anterior, posterior, medial and lateral view, and metatarsals I to V, phalanges I-1 to IV-1 (KUVP 129724), phalanx V-1 (KUVP 133862), and unguals I (KUVP 144767) and III (KUVP 129724) in plantar, lateral, dorsal, medial, proximal and distal views. Dorsal surface in proximal and distal views points upwards. Scale bar $=10 \mathrm{~cm}$ (valid for all bones).

Figure 3: Comparative outline drawings of neosauropod astragali in posterior view. KUVP 142200 (left) is compared to the brachiosaurids Giraffatitan (MB.R.2562, left; traced from Janensch, 1961), the camarasaurid Camarasaurus (AMNH FARB 5761, right reversed; traced from Osborn \& Mook, 1921), and the diplodocid Galeamopus (SMA 0011, left; traced from Tschopp \& Mateus, 2017). Note the expanded shelf with a distinctly convex margin below the fibular facet in the diplodocid Galeamopus (grey arrow). Drawings scaled to equal transverse width in order to highlight shape differences.

Figure 4: Comparative outline drawings of neosauropod metatarsals I in proximal (A) and dorsal view (B). KUVP 129724 (left) is compared with the brachiosaurid Vouivria (MNHN.F.1934.6 DAM 12, left; traced from Mannion et al. 2017) and the flagellicaudatan Galeamopus (SMA 0011, left; traced from Tschopp \& Mateus, 2017). Note the pointed dorsolateral corner of the proximal articular surface in the 
516 brachiosaurids (arrows). Drawings scaled to equal transverse width (A) and proximodistal length (B) in

517 order to highlight shape differences.

518

519 Figure 5: Comparative outline drawings of macronarian metatarsals II in proximal (A) and dorsal view 520 (B). KUVP 129724 (left) is compared with Giraffatitan (MB.R.2181, left; traced from Janensch, 1961) and 521 Camarasaurus (GMNH-PV 101, right reversed; traced from McIntosh et al. 1996). Drawings scaled to 522 equal dorsoplantar height $(A)$ and proximodistal length (B) in order to highlight shape differences.

523

524

525

Figure 6: Comparative outline drawings of macronarian metatarsals IV in proximal (A) and dorsal view

526 (B). KUVP 129724 (left) is compared with Camarasaurus (SMA 0002, right reversed; traced from Tschopp

527 et al. 2015) and Europasaurus (DFMMh-FV886-3, right reversed; photo by E. Tschopp from 2014).

528 Drawings scaled to equal dorsoplantar height $(A)$ and proximodistal length $(B)$ in order to highlight shape differences.

529

530

Figure 7: Shape differences in sauropod metatarsals V. The graph represents morphospace occupation

531 of sauropod $\mathrm{mt} V$ when comparing proximal transverse widths (prW; $x$-axis) and distal transverse widths

532 (diW; y-axis) with proximodistal length (pdL). The left mt V of KUVP 129724 is within the morphospace occupied by titanosauriform sauropods (Brachiosauridae + Somphospondyli), and clearly outside nontitanosauriform macronarians like Camarasaurus and Janenschia. Measurements and sources are provided as supplementary table. Outlines of selected specimens are traced from the following publications: Janenschia robusta SMNS 12144 (right reversed) from a photo taken by J. Nair in 2014, Camarasaurus sp. SMA 0002 (right reversed) from Tschopp et al. (2015), Omeisaurus tianfuensis ZDM

538 T5704 (left) from He et al. (1988), Tastavinsaurus sanzi MPZ 99/9 (right reversed); traced from Canudo et al. (2008), Sonorasaurus thompsoni ASDM 500 (right reversed) from D'Emic et al. (2016),

540 Cedarosaurus weiskopfae DMNH 39045 (right reversed) from D'Emic (2013), and the indeterminate diplodocid MB.R.2371 (left) from a photo taken by E. Tschopp in 2014. The metatarsals are scaled to

542

543

544 Figure 8: Comparative outline drawings of macronarian pedal phalanges I-1 in lateral and distal view. equal proximodistal length to highlight shape differences. 545 KUVP 129724 (left) is compared with the brachiosaurids Sonorasaurus (ASDM 500, right reversed; traced 546 from D'Emic et al. 2016), and Giraffatitan (MB.R.2287, left; Janensch 1961), and the camarasaurid 547 Camarasaurus (SMA 0002, right reversed; traced from Tschopp et al., 2015). Note the straight to 548 concave medial margin of the distal articular surface in the brachiosaurid phalanges, and their elongated 549 shape in lateral view. No lateral view was available from Giraffatitan. Drawings scaled to equal 550 dorsoplantar height in order to highlight shape differences.

551

552

553

554

555

556
Figure 9: Comparative outline drawings of macronarian pedal unguals I and III in lateral view. KUVP 129724 and 144767 (left) are compared with the brachiosaurids Sonorasaurus (ASDM 500, right reversed; traced from D'Emic et al. 2016), and Giraffatitan (MB.R. XX 2, left; Janensch 1961), and the camarasaurid Camarasaurus (SMA 0002, right reversed; traced from Tschopp et al., 2015). No ungual III is known from Sonorasaurus and Giraffatitan. Drawings of unguals I scaled to equal dorsoplantar height 
557 in order to highlight shape differences; drawing of unguals III are scaled proportionally to their

558 respective ungual I to show relative sizes of the unguals in the pedes of the included taxa.

559

560 Figure 10: Geographical map of occurrences of brachiosaurids. The locality of the pes described herein

561 (1) and the type locality of Brachiosaurus altithorax (5) are highlighted in red. The gray area indicates the

562 distribution of the Morrison Formation. 1, Bobcat Pit, Weston County, WY; 2, Freezeout Hills general,

563 Carbon Co., WY; 3, Reed's Quarry 13, Albany Co., WY; 4, Jensen/Jensen Quarry, Uintah Co., UT; 5,

564 Fruita Paleontological Area general, Mesa Co., CO; 6, Riggs Quarry 13, Mesa Co., CO; 7, Dry Mesa

565 Quarry, Mesa Co., CO; 8, Potter Creek Quarry, Montrose Co., CO; 9, Felch Quarry 1, Fremont Co., CO;

566 10, Kenton Pit 1, Cimarron Co., OK. Modified from Bonnan \& Wedel (2004: fig. 2).

567

568 Table 1. Measurements of brachiosaurid pes elements from Bobcat Pit (in mm). Catalog numbers are

569 indicated for the elements not included in KUVP 129724. Asterisks mark widths as preserved in elements

570 with damaged bone surfaces.

571

572 Table 2. Sauropod metatarsal proximodistal lengths of the largest specimens (to our knowledge) of

573 selected species (in $\mathrm{mm}$ ). Ordered after size within major sauropod subclades. Asterisks mark estimated

574 measurements. Specimen numbers and left $(L)$ and right $(R)$ pedes are indicated, and specified with the

575 single measurements where metatarsals of a single pes have different specimen numbers.

576 Supplementary Table 1: Eusauropod metatarsal V elongation. Red ratios are based on measurements

577 taken from figures. 


\section{Figure 1 (on next page)}

Location (A) and quarry maps (B, C) of Bobcat Pit in Weston County, Wyoming.

The astragalus and pes described herein (KUVP 129724, 133862, 142200, 144767) were found associated with the Camarasaurus skeletons KUVP 129713 and 129716 . Quarry maps modified from Bader et al. (2009: figs 2, 4). 


\section{Figure 2}

Single bones of the brachiosaurid pes described herein.

Astragalus KUVP 142200 in proximal, distal, anterior, posterior, medial and lateral view, and metatarsals I to V, phalanges I-1 to IV-1 (KUVP 129724), phalanx V-1 (KUVP 133862), and unguals I (KUVP 144767) and III (KUVP 129724) in plantar, lateral, dorsal, medial, proximal and distal views. Dorsal surface in proximal and distal views points upwards. Scale bar $=10$ $\mathrm{cm}$ (valid for all bones).

*Note: Auto Gamma Correction was used for the image. This only affects the reviewing manuscript. See original source image if needed for review. 


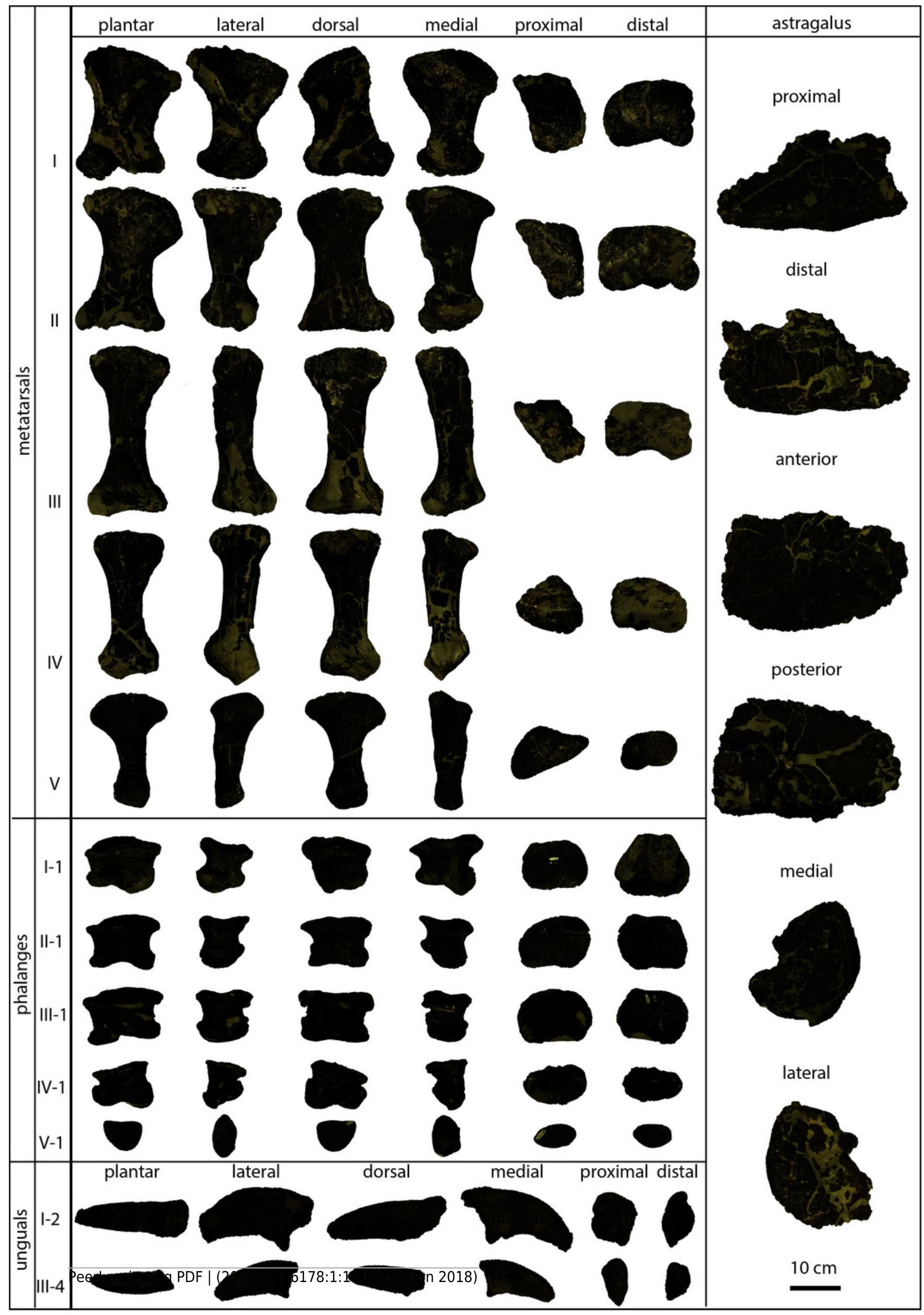




\section{Figure 3 (on next page)}

Comparative outline drawings of neosauropod astragali in posterior view.

KUVP 142200 (left) is compared to the brachiosaurids Giraffatitan (MB.R.2562, left; traced from Janensch, 1961), the camarasaurid Camarasaurus (AMNH FARB 5761, right reversed; traced from Osborn \& Mook, 1921), and the diplodocid Galeamopus (SMA 0011, left; traced from Tschopp \& Mateus, 2017). Note the expanded shelf with a distinctly convex margin below the fibular facet in the diplodocid Galeamopus (grey arrow). Drawings scaled to equal transverse width in order to highlight shape differences. 
KUVP P\$42200

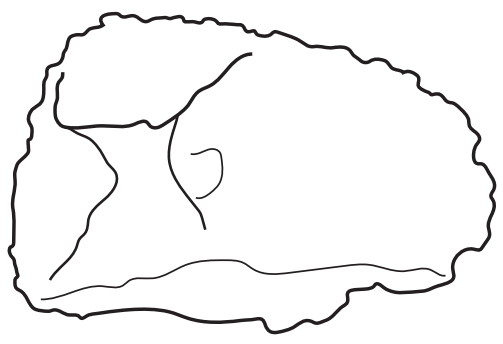

Camarasaurus

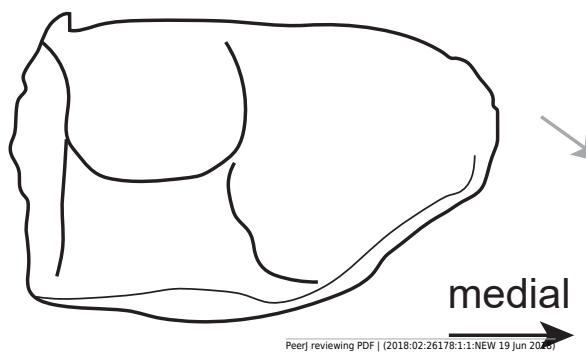

Manuscript to Giraffratitan

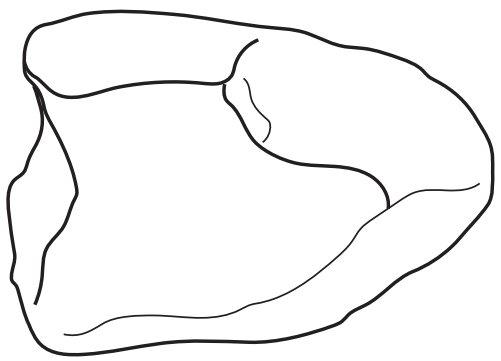

Galeamopus

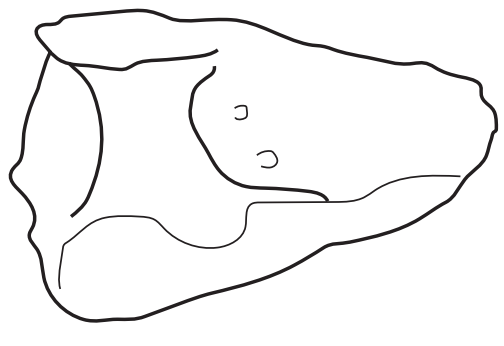


Figure 4 (on next page)

Comparative outline drawings of neosauropod metatarsals I in proximal $(A-C)$ and dorsal view (D-F).

KUVP 129724 (A, D; left metatarsal) is compared with the brachiosaurid Vouivria MNHN.F.1934.6 DAM 12 (B, E; left metatarsal; traced from Mannion et al. 2017) and the flagellicaudatan Galeamopus SMA 0011 (C, F; left metatarsal; traced from Tschopp \& Mateus, 2017). Note the pointed dorsolateral corner of the proximal articular surface in the brachiosaurids (arrows). Drawings scaled to equal transverse width (A-C) and proximodistal length (D-F) in order to highlight shape differences. 


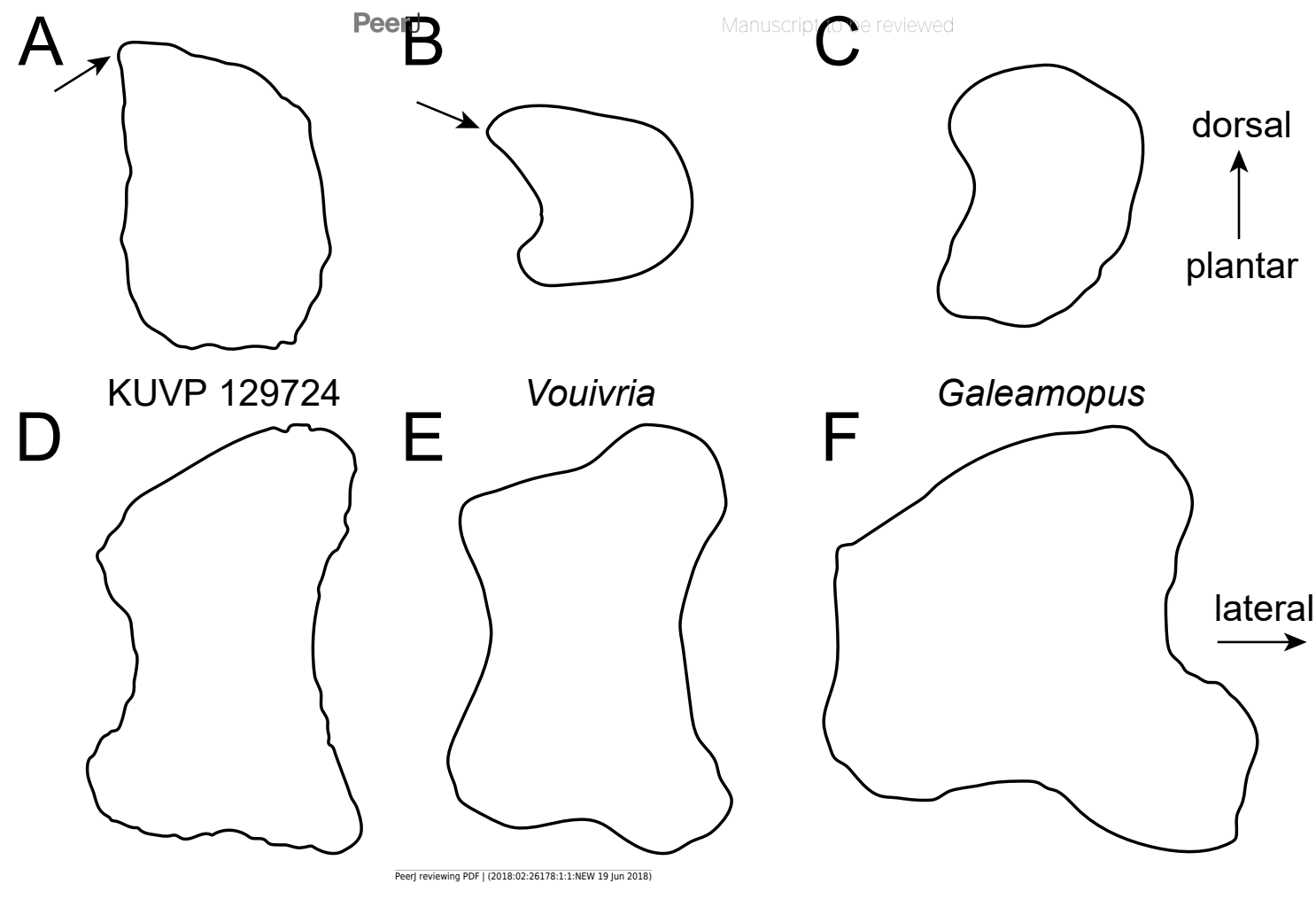


Figure $\mathbf{5}$ (on next page)

Comparative outline drawings of macronarian metatarsals II in proximal (A-C) and dorsal view (D-F).

KUVP 129724 (A, D; left metatarsal) is compared with Giraffatitan MB.R.2181 (B, E; left metatarsal; traced from Janensch, 1961) and Camarasaurus GMNH-PV 101 (C, F; right metatarsal reversed; traced from McIntosh et al. 1996). Drawings scaled to equal dorsoplantar height $(A-C)$ and proximodistal length (D-F) in order to highlight shape differences. 


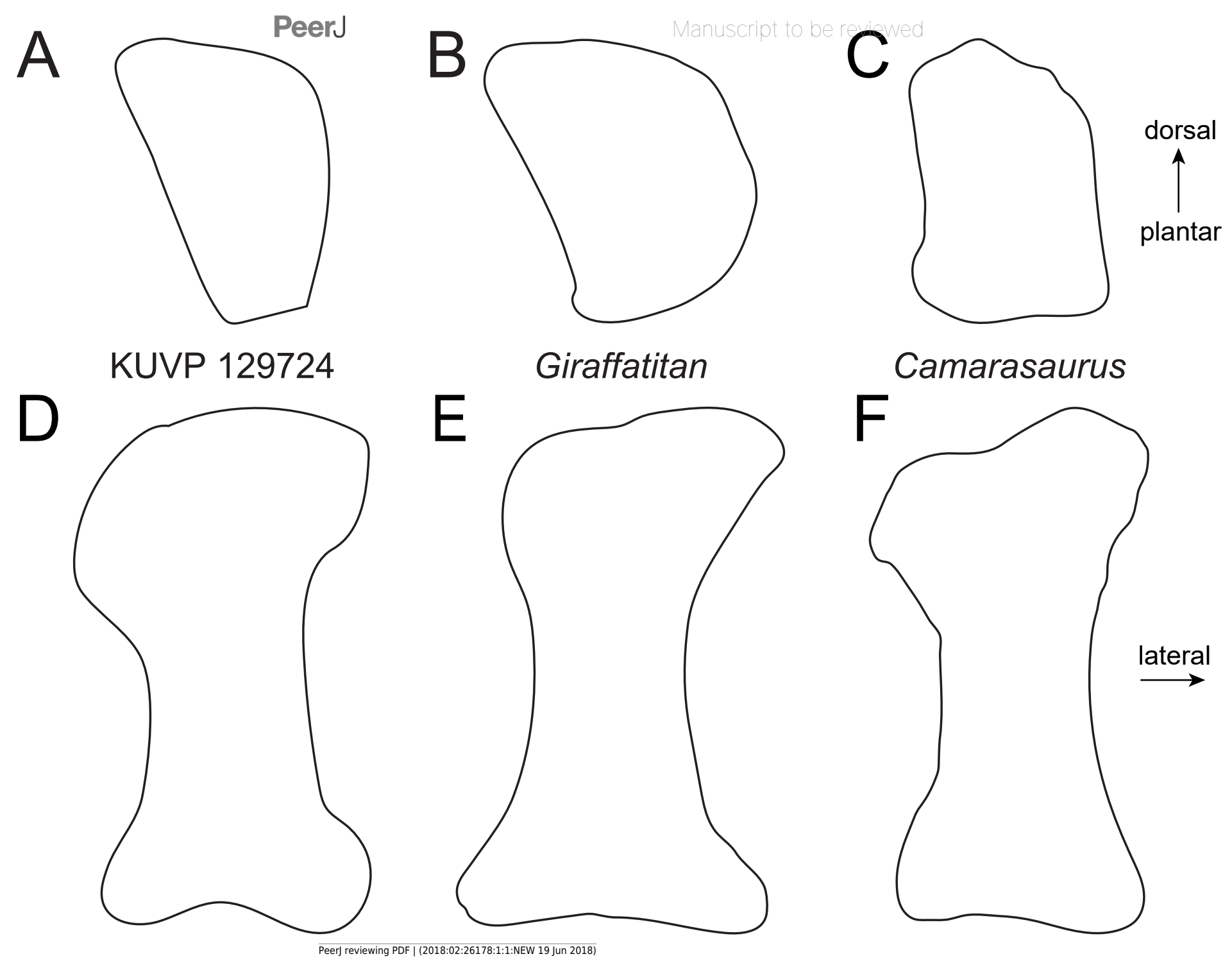


Figure 6 (on next page)

Comparative outline drawings of macronarian metatarsals IV in proximal $(A-C)$ and dorsal view (D-F).

KUVP 129724 (A, D; left metatarsal) is compared with Camarasaurus SMA 0002 (B, E; right metatarsal reversed; traced from Tschopp et al. 2015) and Europasaurus DFMMh-FV886-3 (C, F; right metatarsal reversed; traced from photo by E. Tschopp from 2014). Drawings scaled to equal dorsoplantar height $(A-C)$ and proximodistal length (D-F) in order to highlight shape differences. 


\section{Figure 7 (on next page)}

Shape differences in sauropod metatarsals V.

The graph represents morphospace occupation of sauropod $\mathrm{mt} \mathrm{V}$ when comparing proximal transverse widths (prW; $x$-axis) and distal transverse widths (diW; $y$-axis) with proximodistal length (pdL). The left $\mathrm{mt} \mathrm{V}$ of KUVP 129724 is within the morphospace occupied by titanosauriform sauropods (Brachiosauridae + Somphospondyli), and clearly outside nontitanosauriform macronarians like Camarasaurus and Janenschia. Measurements and sources are provided as supplementary table. Outlines of selected specimens are traced from the following publications: Janenschia robusta SMNS 12144 (right reversed) from a photo taken by J. Nair in 2014, Camarasaurus sp. SMA 0002 (right reversed) from Tschopp et al. (2015), Omeisaurus tianfuensis ZDM T5704 (left) from He et al. (1988), Tastavinsaurus sanzi MPZ 99/9 (right reversed); traced from Canudo et al. (2008), Sonorasaurus thompsoni ASDM 500 (right reversed) from D'Emic et al. (2016), Cedarosaurus weiskopfae DMNH 39045 (right reversed) from D'Emic (2013), and the indeterminate diplodocid MB.R.2371 (left) from a photo taken by E. Tschopp in 2014. The metatarsals are scaled to equal proximodistal length to highlight shape differences. 


\section{Figure 8 (on next page)}

Comparative outline drawings of macronarian pedal phalanges I-1 in lateral and distal view.

KUVP 129724 (left) is compared with the brachiosaurids Sonorasaurus (ASDM 500, right reversed; traced from D'Emic et al. 2016), and Giraffatitan (MB.R.2287, left; Janensch 1961), and the camarasaurid Camarasaurus (SMA 0002, right reversed; traced from Tschopp et al., 2015). Note the straight to concave medial margin of the distal articular surface in the brachiosaurid phalanges, and their elongated shape in lateral view. No lateral view was available from Giraffatitan. Drawings scaled to equal dorsoplantar height in order to highlight shape differences. 
KUVP 129724
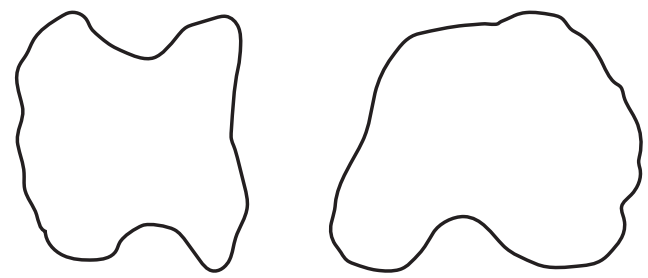

Sonorasaurus

Giraffatitan
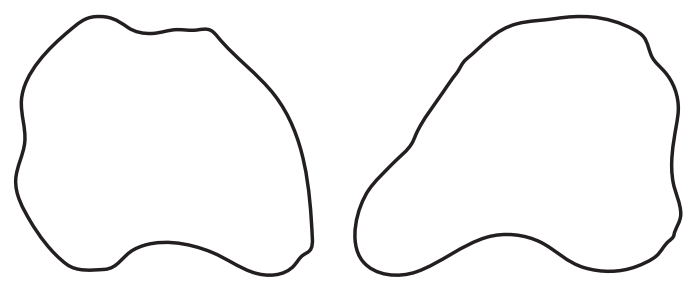

Camarasaurus
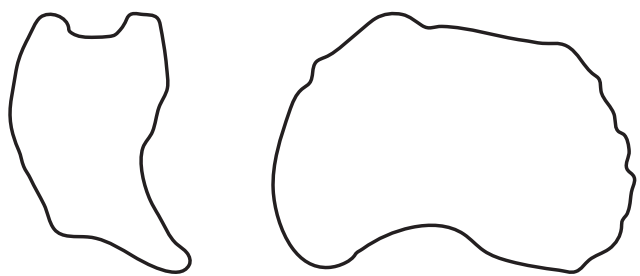


\section{Figure 9 (on next page)}

Comparative outline drawings of macronarian pedal unguals I and III in lateral view.

KUVP 129724 and 144767 (left) are compared with the brachiosaurids Sonorasaurus (ASDM 500, right reversed; traced from D'Emic et al. 2016), and Giraffatitan (MB.R. XX 2, left; Janensch 1961), and the camarasaurid Camarasaurus (SMA 0002, right reversed; traced from Tschopp et al., 2015). No ungual III is known from Sonorasaurus and Giraffatitan. Drawings of unguals I scaled to equal dorsoplantar height in order to highlight shape differences; drawing of unguals III are scaled proportionally to their respective ungual I to show relative sizes of the unguals in the pedes of the included taxa. 
KUVP 144767

ungual I

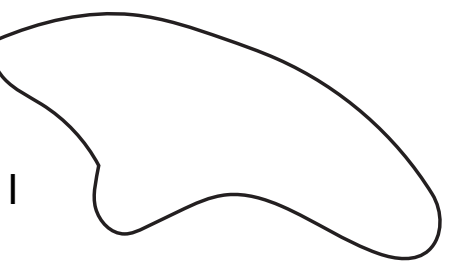

KUVP 129724
Sonorasaurus

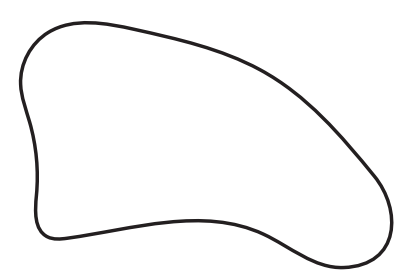

Giraffatitan

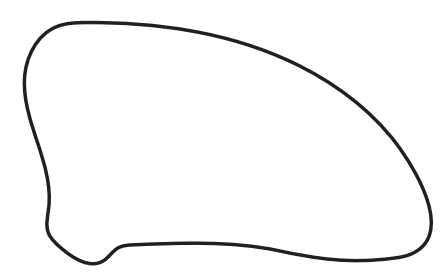

\section{Camarasaurus}

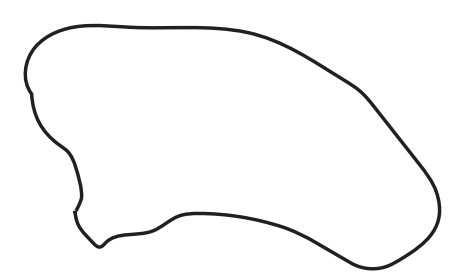

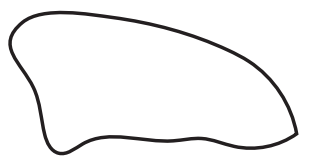

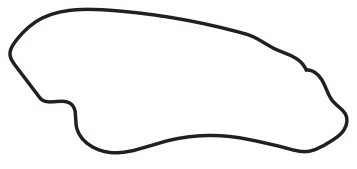


Figure 10 (on next page)

Map of occurrences of Brachiosauridae in the Upper Jurassic Morrison Formation.

The locality of the pes described herein (1) and the type locality of Brachiosaurus altithorax (5) are highlighted in red. The gray area indicates the distribution of the Morrison Formation. 1, Bobcat Pit, Weston County, WY; 2, Freezeout Hills general, Carbon Co., WY; 3, Reed's Quarry 13, Albany Co., WY; 4, Jensen/Jensen Quarry, Uintah Co., UT; 5, Fruita Paleontological Area general, Mesa Co., CO; 6, Riggs Quarry 13, Mesa Co., CO; 7, Dry Mesa Quarry, Mesa Co., CO; 8, Potter Creek Quarry, Montrose Co., CO; 9 , Felch Quarry 1, Fremont Co., CO; 10, Kenton Pit 1, Cimarron Co., OK. Modified from Bonnan \& Wedel (2004: fig. 2). 


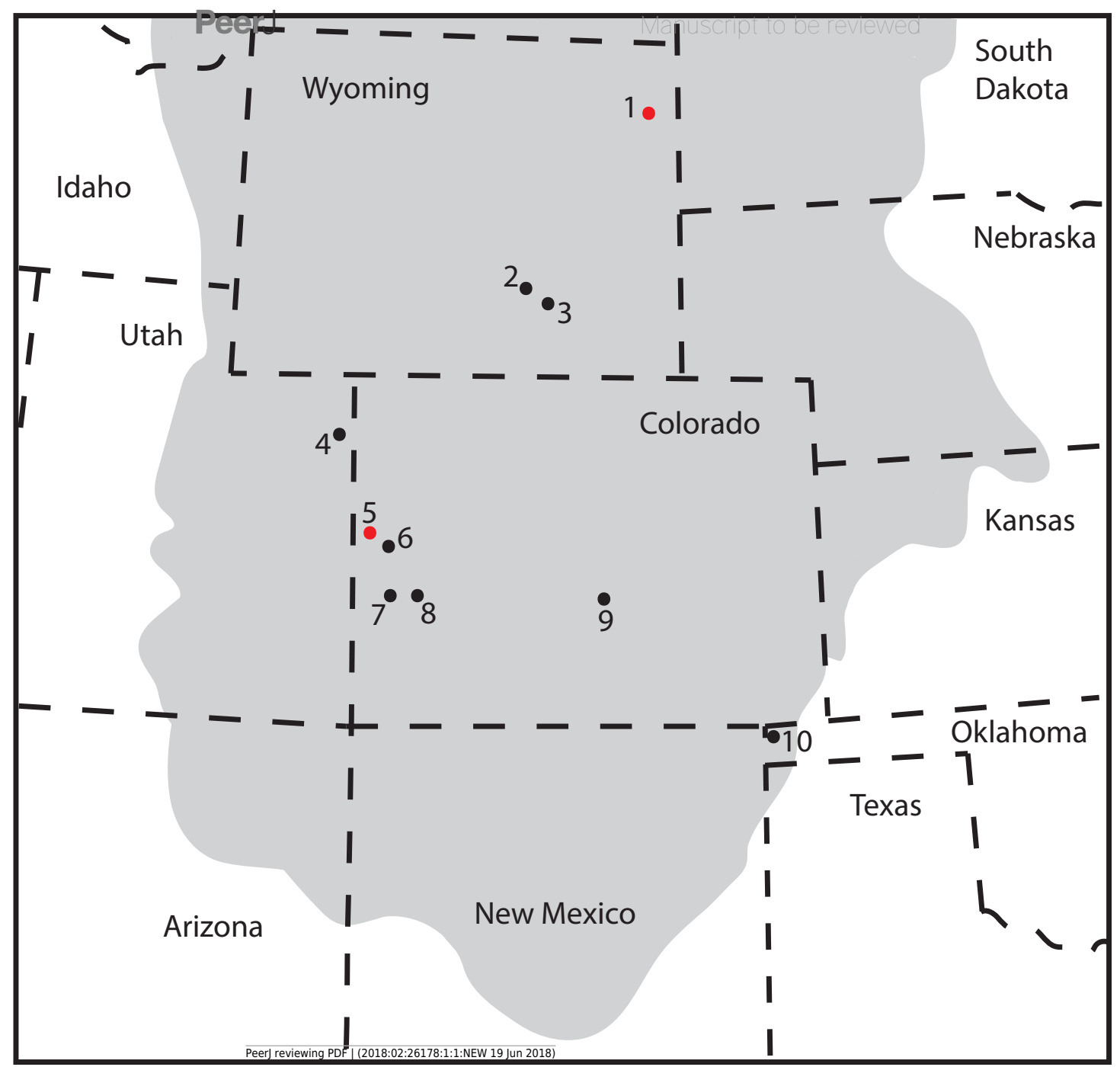




\section{Table $\mathbf{1}$ (on next page)}

Measurements of brachiosaurid pes elements from Bobcat Pit (in mm).

Catalog numbers are indicated for the elements not included in KUVP 129724. Asterisks mark widths as preserved in elements with damaged bone surfaces. Abbreviations: $\mathrm{mt}$, metatarsal; php, pedal phalanx. 
Table 1. Measurements of brachiosaurid pes elements from Bobcat Pit (in mm). Catalog numbers are indicated for the elements not included in KUVP 129724. Asterisks mark widths as preserved in elements with damaged bone surfaces.

\begin{tabular}{|c|c|c|c|c|}
\hline Element & Length & Proximal Width & Distal Width & Field Number \\
\hline Astragalus (KUVP 142200) & 246 & 370 & & - \\
\hline $\mathrm{mt} \mathrm{I}$ & 266 & 133 & 167 & BP099 \\
\hline mt II & 290 & 163 & 183 & ВР098 \\
\hline mt III & 332 & $134^{*}$ & 156 & ВР097 \\
\hline $\mathrm{mt}$ IV & 329 & 154 & $134^{*}$ & BP145 \\
\hline $\mathrm{mt} \mathrm{V}$ & 269 & 182 & 91 & ВР096 \\
\hline php I-1 & 101 & 132 & 102 & BP208 \\
\hline php II-1 & 100 & 147 & 130 & ВР013 \\
\hline php III-1 & 81 & 135 & 123 & BP194 \\
\hline php ?IV-1 & 80 & 99 & 105 & BP185 \\
\hline php ?V-1 (KUVP 133862) & 52 & 68 & & - \\
\hline Ungual ?III-4 & 185 & 52 & & BP014 \\
\hline
\end{tabular}




\section{Table 2 (on next page)}

Sauropod metatarsal proximodistal lengths of the largest specimens (to our knowledge) of selected species (in $\mathrm{mm}$ ), ordered after size within major sauropod subclades.

Asterisks mark estimated measurements. Specimen numbers and left $(\mathrm{L})$ and right $(\mathrm{R})$ pedes are indicated, and specified with the single measurements where metatarsals of a single pes have different specimen numbers. 


\begin{tabular}{|c|c|c|c|c|c|c|}
\hline \multicolumn{7}{|c|}{$\begin{array}{l}\text { Table 2. Sauropod metatarsal pro } \\
\text { selected species (in mm). Ordere } \\
\text { estimated measurements. Specin } \\
\text { specified with the single measure } \\
\text { numbers. } \\
\text { Non-neosauropod Eusauropoda }\end{array}$} \\
\hline & Turiasaurus & Jobaria & Omeisaurus & Cetiosauriscu & Omeisaurus & Shunosaurus \\
\hline & & & & $s$ & & \\
\hline & riodevensis & tiguidensis & tianfuensis & stewarti & tianfuensis & III \\
\hline & CPT; L & MNN TIG4 & $\begin{array}{r}\text { ZDM } \\
\text { T5704; } R\end{array}$ & $\begin{array}{l}\text { NHMUK } \\
\text { R3078; L }\end{array}$ & ZDM T5701; & ZDM T5402; L \\
\hline $\begin{array}{l}\text { Metatar } \\
\text { sal I }\end{array}$ & $\begin{array}{c}230 \text { (CPT- } \\
1318)\end{array}$ & & 165 & 152 & 192 & 110 \\
\hline $\begin{array}{l}\text { Metatar } \\
\text { sal II }\end{array}$ & $\begin{array}{r}300 \text { (CPT- } \\
1309)\end{array}$ & & 215 & 204 & 202 & 150 \\
\hline $\begin{array}{l}\text { Metatar } \\
\text { sal III }\end{array}$ & $\begin{array}{r}300 \text { (CPT- } \\
3967)\end{array}$ & 300 & & 212 & & 180 \\
\hline $\begin{array}{l}\text { Metatar } \\
\text { sal IV }\end{array}$ & $\begin{array}{r}280 \text { (CPT- } \\
1268)\end{array}$ & & & 207 & & \\
\hline $\begin{array}{l}\text { Metatar } \\
\text { sal V }\end{array}$ & $\begin{array}{r}245 \text { (CPT- } \\
3965)\end{array}$ & & & 187 & & \\
\hline Source & $\begin{array}{l}\text { R. Royo- } \\
\text { Torres, pers. } \\
\text { comm. } 2018\end{array}$ & $\begin{array}{r}\text { Sereno et } \\
\text { al. } 1999\end{array}$ & $\begin{array}{r}\text { He et al. } \\
1988\end{array}$ & $\begin{array}{r}\text { E Tschopp, } \\
\text { pers. obs. } \\
2011\end{array}$ & $\begin{array}{r}\text { He et al. } \\
1988\end{array}$ & Zhang 1988 \\
\hline \multicolumn{7}{|c|}{ Diplodocoidea } \\
\hline & ?Barosaurus & $\begin{array}{r}\text { Apatosaur } \\
\text { us }\end{array}$ & Diplodocus & Suuwassea & Galeamopus & Dyslocosaurus \\
\hline & lentus & louisae & carnegii & emilieae & pabsti & polyonychius \\
\hline & $\begin{array}{r}\text { ?CM 11984; } \\
\text { L }\end{array}$ & CM 3018; L & CM 94; L & $\begin{array}{r}\text { ANS 21122; } \\
\mathrm{R}\end{array}$ & SMA 0011; L & AC 663; L \\
\hline $\begin{array}{l}\text { Metatar } \\
\text { sal I }\end{array}$ & 208 & 195 & 163 & 130.7 & 124 & 123 \\
\hline $\begin{array}{l}\text { Metatar } \\
\text { sal II }\end{array}$ & 217 & 213 & 191 & 154.3 & 153 & 140 \\
\hline $\begin{array}{l}\text { Metatar } \\
\text { sal III }\end{array}$ & 242 & 236 & 213 & & 164 & 171 \\
\hline $\begin{array}{l}\text { Metatar } \\
\text { sal IV }\end{array}$ & 239 & 236 & 206 & 172.8 & 180 & \\
\hline $\begin{array}{l}\text { Metatar } \\
\text { sal V }\end{array}$ & 231 & & 160 & & 178 & \\
\hline Source & $\begin{array}{r}\text { Mclntosh } \\
2005\end{array}$ & $\begin{array}{r}\text { Gilmore } \\
1936\end{array}$ & $\begin{array}{r}\text { Hatcher } \\
1901 ; \\
\text { Mclntosh et } \\
\text { al. } 1992\end{array}$ & Harris 2007 & $\begin{array}{r}\text { Tschopp \& } \\
\text { Mateus } 2017\end{array}$ & $\begin{array}{r}\text { McIntosh et al. } \\
1992\end{array}$ \\
\hline
\end{tabular}




\begin{tabular}{|c|c|c|c|c|c|c|}
\hline & $\begin{array}{r}\text { Camarasaur } \\
\text { us }\end{array}$ & $\begin{array}{r}\text { Camarasau } \\
\text { rus }\end{array}$ & $\begin{array}{r}\text { Camarasau } \\
\text { rus }\end{array}$ & Janenschia & $\begin{array}{r}\text { Camarasaur } \\
\text { us }\end{array}$ & Camarasaurus \\
\hline & supremus & grandis & grandis & robusta & sp. & lentus \\
\hline & $\begin{array}{r}\text { AMNH FARB } \\
5761 ; \mathrm{R}\end{array}$ & $\begin{array}{r}\text { GMNH-PV } \\
101 ; \mathrm{R}\end{array}$ & $\begin{array}{r}\text { YPM } \\
\text { VP.001905; } \\
\mathrm{L}\end{array}$ & $\begin{array}{r}\text { SMNS 12144; } \\
\mathrm{R}\end{array}$ & SMA 0002; R & CM 11338; L \\
\hline $\begin{array}{l}\text { Metatar } \\
\text { sal I }\end{array}$ & & 172 & 133 & 140 & 113 & 70 \\
\hline $\begin{array}{l}\text { Metatar } \\
\text { sal II }\end{array}$ & & 193 & 174 & 160 & 134 & 90 \\
\hline $\begin{array}{l}\text { Metatar } \\
\text { sal III }\end{array}$ & 225 & 223 & 182 & 160 & 133 & 88 \\
\hline $\begin{array}{l}\text { Metatar } \\
\text { sal IV }\end{array}$ & & 206 & 165 & 150 & 112 & 80 \\
\hline $\begin{array}{l}\text { Metatar } \\
\text { sal V }\end{array}$ & & 166 & 125 & 115 & 108 & 60 \\
\hline Source & $\begin{array}{r}\text { Osborn \& } \\
\text { Mook, } 1921\end{array}$ & $\begin{array}{r}\text { Mclntosh } \\
\text { et al. } 1996\end{array}$ & $\begin{array}{r}\text { E Tschopp } \\
\& \text { O } \\
\text { Mateus, } \\
\text { pers. obs. } \\
2014 \\
\end{array}$ & $\begin{array}{l}\text { Fraas, 1908; } \\
\text { J. Nair, pers. } \\
\text { comm. } 2015\end{array}$ & $\begin{array}{r}\text { Tschopp et } \\
\text { al. 2015b }\end{array}$ & Gilmore, 1925 \\
\hline \multicolumn{7}{|c|}{ Brachiosauridae } \\
\hline & $\begin{array}{r}\text { Brachiosauri } \\
\text { dae }\end{array}$ & $\begin{array}{r}\text { Giraffatita } \\
n\end{array}$ & $\begin{array}{r}\text { Sonorasaur } \\
\text { us }\end{array}$ & Vouivria & $\begin{array}{r}\text { Cedarosauru } \\
s \\
\end{array}$ & Venenosaurus \\
\hline & indet. & brancai & thompsoni & $\begin{array}{r}\text { damparisensi } \\
s\end{array}$ & weiskopfae & dicrocei \\
\hline & $\begin{array}{r}\text { KUVP } \\
129724 ; \mathrm{L}\end{array}$ & MB.R.2181 & $\begin{array}{r}\text { ASDM 500; } \\
\mathrm{R}\end{array}$ & $\begin{array}{r}\text { MNHN.F.193 } \\
4.6 ; \mathrm{L}\end{array}$ & $\begin{array}{l}\text { DMNS } \\
\text { 39045; }\end{array}$ & $\begin{array}{r}\text { DMNS 40932; } \\
\mathrm{R}\end{array}$ \\
\hline $\begin{array}{l}\text { Metatar } \\
\text { sal I }\end{array}$ & 266 & & 194 & 175 & 165 & 128 \\
\hline $\begin{array}{l}\text { Metatar } \\
\text { sal II }\end{array}$ & 290 & 276 & 242 & & 205 & \\
\hline $\begin{array}{l}\text { Metatar } \\
\text { sal III }\end{array}$ & 332 & & & 234 & & 172 \\
\hline $\begin{array}{l}\text { Metatar } \\
\text { sal IV }\end{array}$ & 329 & & 261 & & 247 & 180 \\
\hline $\begin{array}{l}\text { Metatar } \\
\text { sal V }\end{array}$ & 269 & & 221 & & & \\
\hline Source & this study & Paul 1988 & $\begin{array}{r}\text { D'Emic et } \\
\text { al. } 2016\end{array}$ & $\begin{array}{r}\text { Mannion et } \\
\text { al. } 2017\end{array}$ & $\begin{array}{r}\text { A Maltese, } \\
\text { pers. obs., } \\
2012 \\
\end{array}$ & $\begin{array}{r}\text { A Maltese, } \\
\text { pers. obs., } \\
2012 \\
\end{array}$ \\
\hline \multicolumn{7}{|c|}{ Somphospondyli } \\
\hline & $\begin{array}{r}\text { Dreadnough } \\
\text { tus }\end{array}$ & $\begin{array}{r}\text { Alamosaur } \\
\text { us }\end{array}$ & $\begin{array}{r}\text { Tastavinsau } \\
\text { rus }\end{array}$ & $\begin{array}{r}\text { Ligabuesauru } \\
s\end{array}$ & Notocolossus & $\begin{array}{r}\text { Opisthocoelica } \\
\text { udia }\end{array}$ \\
\hline & schrani & $\begin{array}{r}\text { sanjuanens } \\
\text { is }\end{array}$ & sanzi & leanzai & $\begin{array}{r}\text { gonzalezpare } \\
\text { jasi }\end{array}$ & skarzynskii \\
\hline
\end{tabular}




\begin{tabular}{|l|r|r|r|r|r|r|}
\hline & $\begin{array}{r}\text { MPM-PV } \\
\text { 1156; R }\end{array}$ & $\begin{array}{r}\text { NMMNH P- } \\
\text { 49967; R }\end{array}$ & $\begin{array}{r}\text { MPZ 99/9; } \\
\text { R }\end{array}$ & $\begin{array}{r}\text { MCF-PHV- } \\
233 ; R\end{array}$ & $\begin{array}{r}\text { UNCUYO-LD } \\
302 ; ~ R\end{array}$ & $\begin{array}{r}\text { ZPAL MgD- } \\
\text { I/48; R }\end{array}$ \\
\hline $\begin{array}{l}\text { Metatar } \\
\text { sal I }\end{array}$ & 210 & 195 & 162 & 140 & 164 & 150 \\
\hline $\begin{array}{l}\text { Metatar } \\
\text { sal II }\end{array}$ & 250 & 245 & 190 & 190 & 185 & 180 \\
\hline $\begin{array}{l}\text { Metatar } \\
\text { sal III }\end{array}$ & & 270 & 230 & 220 & 197 & 200 \\
\hline $\begin{array}{l}\text { Metatar } \\
\text { sal IV }\end{array}$ & & 291 & 212 & 220 & 218 & 180 \\
\hline $\begin{array}{l}\text { Metatar } \\
\text { sal V }\end{array}$ & & 281 & 180 & 180 & 196 & 140 \\
\hline $\begin{array}{l}\text { Source } \\
\text { Lacovara et } \\
\text { al. 2014 }\end{array}$ & $\begin{array}{r}\text { D'Emic et } \\
\text { al. 2011 }\end{array}$ & $\begin{array}{r}\text { Canudo et } \\
\text { al. 2008 }\end{array}$ & $\begin{array}{r}\text { Bonaparte et } \\
\text { al. 2006 }\end{array}$ & $\begin{array}{r}\text { González } \\
\text { Riga et al. } \\
2016\end{array}$ & $\begin{array}{r}\text { Borsuk- } \\
\text { Bialynicka } \\
1977\end{array}$ \\
\hline
\end{tabular}

1 